\title{
Unit Per Deciliter
}

National Cancer Institute

\section{Source}

National Cancer Institute. Unit Per Deciliter. NCI Thesaurus. Code C105521.

An arbitrary unit of substance concentration expressed in unit(s) per deciliter. 